\title{
Cultural and Natural Roots of Puerto Rican Mestizaje in Rosario Ferrés The House on the Lagoon
}

\author{
BABETt RubóczKi \\ babett.ruboczki@gmail.com
}

\begin{abstract}
The paper explores the conversational orchestration of family anecdotes as a dominant experimental narrative strategy underlying Puerto Rican author Rosario Ferrés historical novel, The House on the Lagoon. The study reads Ferrés narrative through Mikhail Bakhtin's philosophy of the dialogic nature of language to highlight the interplay between environmental and cultural images of hybridity. The close reading of this representative piece of US Caribbean literature elucidates how Ferré utilizes the dialogic form to contest the Puerto Rican cultural and national politics that tend to suppress and silence the nonwhite (black and indigenous) components of Puerto Rican identity.
\end{abstract}

Keywords: dialogism, environment, cultural hybridity, US Caribbean literature

\section{Introduction}

As a prominent representative of the post-1970s Puerto Rican literary tradition, the nueva narrative (new narrative), the island-born Rosario Ferré has always been considered an author of ambivalence. Her first works-Papeles de Pandora and Maldito Amor, published in 1976 and 1986, respectively-established her reputation among the island-based literary community as a writer who constantly pushes the boundaries of Puerto Rican literary traditions by engaging with the contradictions underlying Puerto Rican national identity, gender, and racial politics. Ferrés oeuvre attests to the innately political sensibilities of her works which reflect the ways Puerto Rican cultural identity is complicated by the island's Spanish colonial history and its twentieth-century political status as an unincorporated territory of the United States. Accordingly, most of Ferré's works reflect the author's personal conviction regarding Puerto Rico's Commonwealth status - a semi-autonomous form which economically and politically ties the country to the US - and challenges the internal division within Puerto Rican culture this status has created by tearing the country into largely two political camps, the supporters of statehood and the advocates of independence.

Ferrés novel, The House on the Lagoon, exposes the complex and multilayered roots fueling these national frictions. As a result, it presents the readers with a historically 
imbued family narrative that discloses the racial, political, and national differences that plague Puerto Rican society. However, it is not only the addressed themes of cultural identity, racism, feminism, and national autonomy that, following the publication of the novel, generated a torrent of harsh criticism targeting Ferrés literary and political persona. Breaking with the conventional Puerto Rican literary practice of writing in Spanish - a gesture signaling the island's independence from American cultural and linguistic influences-Ferré published The House on the Lagoon in English first and self-translated the novel into Spanish in 1996, with the title La Casa de la Laguna (Esplin 2015, 23). Her linguistic choice was characterized by many island-based writers and cultural representatives as "an unthinkable heresy" committed against her own island roots (Johnson 2008, 239). As Marlene Hansen Esplin thoughtfully notes, Ferrés language politics epitomizes her underlying poetics of contradiction that unsettles the binary constructions of mainland and island and opens up the dialogue between the American and insular Puerto Rican conceptions of cultural, ethnic, and national identity $(2005,25)$. As Lyn Di Iorio Sandín remarks, the theme of ambivalence surrounding bicultural identity constitutes an underexplored connective link between US Caribbean and US Latino/a literatures (2004, 11). In line with Sandín's thought, I contend that my analysis highlights the value of Ferrés work for a hemispheric approach to US Caribbean literature and demonstrates the ways the culturally hybrid formations of identity transgress national and geographical borders.

Addressing the ambivalences undergirding the cultural history of Puerto Rico, the ensuing analysis demonstrates how Ferrés transgenerational family novel, The House on the Lagoon, uses a multi-dimensional dialogic structure to subvert the erasure and silencing of Puerto Rico's collective history of cultural hybridity. Through the investigation of the experimental form and innovative narrative techniques evident in metatextuality and the fragmentation of time and place, I will demonstrate that the novel foregrounds the complexity and the multiple dimensions of the Puerto Rican cultural identity. Set on the island, Ferrés novel centers on writer-poet Isabel Mendizabal, whose manuscript—written in the course of the novel—narratively challenges her husband, Quintín Mendizabal's family genealogy and debunks the bourgeois merchant family's falsely maintained pure Spanish bloodline. The novel is organized as a written dialogue between husband and wife, in which Quintín's notes on her wife's writerly aptitude and, especially, his evaluative remarks regarding the truth value of Isabel's family accounts constantly interrupt the narrative. Considering that, I argue that the conflicting voices and narratives presented in the novel expose an insular anxiety over the Puerto Rican mestizaje, the culturally hybrid identity which, in Marisel C. Moreno's definition, was developed through the intermixing of African black, indigenous Taíno, Spanish European, and American cultures $(2012,52)$. 
To highlight the dialogic structure of Ferrés narrative, I draw on the liberating potential Mikhail M. Bakhtin attributes to his narrative concept of dialogism. Bakhtin's notion of dialogism underlines that the inherently hybrid construction of every single utterance - which always contains within itself at least "two utterances, two speech manners, [...] two semantic and axiological belief systems" (304)_ liberates the consciousness from monologism, that is, "the hegemony of a single and unitary language [...] as an absolute form of thought" $(1981,367)$. Bakhtin's liberating configuration of dialogism and his related concept of heteroglossia are appropriate analytical tools to uncover and discuss different facets of the insular perspectives of the hybrid Puerto Rican identity the selected work portrays. To substantiate Ferrés novel as heteroglot, I will demonstrate "the co-existence of socio-ideological contradictions" (Bakhtin 1981, 291) between the unofficial and official histories of Puerto Rican mestizaje. I explore how the family narratives give voice to silenced Puerto Rican social groups-including women, blacks, and mulatto/as (referring to people with a mixed African and Anglo-European ancestry) - to expose and interrogate the insular politics of effacing the collective histories of cultural mixture. The operation of Bakhtin's dialogic force related to heteroglossia in The House on the Lagoon will reveal how the work's dominant theme regarding the interplay between the Caribbean discourses of nature and culture also yields interpretations of the subthemes of home and matrilineal heritage. The following analysis will examine the interplay of environmental and cultural images as they engage with and problematize the hybrid nature of Puerto Rican cultural identity.

\section{Home and Hybridity}

Home as an intersubjective space binding together humans and nature is a central metaphor in The House on the Lagoon. In the novel, home is deeply grounded in the Caribbean natural environment; the characters have an interdependent relationship with their surrounding ecosystem, which sustains their families economically, physically, and mentally. Ferrés rendering of the eponymous house on the lagoon sheds light on harmful insular discourses that efface the symbiotic relationship between the cultural arena of the house and its surrounding amphibious environment. The decentralizing power that Bakhtin ascribes to heteroglossia to disrupt monolithic ideological discourses $(1981,367)$ is evident in the dialogic interplay between the Mendizabals' house and its surrounding aquatic environment. The fluidity of the waterways that connect the wealthy Puerto Rican family's home on the lagoon and the swamp populated by native black people shatters the dominant Puerto Rican national myth of clear-cut racial and class boundaries between the white upper- 
class and the black working-class population. The easily permeable natural borders between the house and the swamp ensure regular contacts between these two sides resulting in a transgenerational family history of tabooed miscegenations. The male members of the family cross the waters for economic purposes and erotic pleasures: on the one hand, they ship blacks from the slum of the Morass Lagoon to employ them as house servants, and on the other, they frequent those places to gratify their sexual desires with Afro-Mestiza women.

The natural world of the mangrove swamp - the crossroads of the waterways upon which the Mendizabal house is built-is a central ecological motif that reflects the conflicting narratives between cultural hybridity and the national ideology of whiteness. In an interview Ferré points out the metaphoric significance of the botanical feature of the mangrove swamp and the location of the house:

The title [of the novel] refers to the fact that the Mendizabals's [sic!] house is built on a mangrove swamp, which is halfway territory: half earth, half water. [...] And Puerto Rico is a lot like that, it's a borderline country. Puerto Ricans are hybrid people: Hispanic and American, part Caribbean Indian and part African, and many other things. [...] This ambivalence has been our problem, because it's very hard to be two things at the same time. (qtd. in Kevane 2000, 66)

The double-rooted terrain of the swamp, which provides the architectural foundation of the house, unveils the hybrid construction of the Puerto Rican identity, which the Mendizabal family — as the national representative of racial purity—denies, yet, frequently exploits. Thus, the simultaneously aquatic and terrestrial ground of the house also mirrors the ambivalent foundation of the twentieth-century Puerto Rican nation which, as Moreno stresses, seems to welcome mestizaje yet, at the same time, conceals the ongoing colonial ideologies of bloodline purity $(2012,53)$.

The diverse ecosystem of the mangrove swamp functions as an ecological representation of the Mendizabal family's mixed bloodline that metonymically foreshadows as well as foregrounds the complexity of the family relations and roots. The first chapter of Isabel's family saga, "Foundations," describes how impenetrable and inexplicable this territory is:

The swamp was a mysterious place, full of exotic wildlife and strange botanical specimens, with creatures both amphibious and terrestrial. The mangroves had bushy tops with all sort of birds nesting in them [...] But the mangroves were also aquatic, and their roots spread an intricate maze over water. Inside the labyrinths of knots and sinews a whole universe of mollusks, crustaceans, and fish proliferated freely, half immersed in the mud, half encrusted in the mossy cartilage of the wood. It was a strange territory to navigate in, and although several wide channels crossed it from end to end, if one were to get lost in its tangle, there was only a slim chance of finding one's way out. (Ferré 1996, 10) 
This "intricate maze over water" (Ferré 1996, 10) that encompasses diverse classes of species metaphorically mirrors the composite nature of the Mendizabals' cultural foundations. Analogously to the entangled and hybrid ecological roots which the house is architecturally constructed on, the family is prefigured to be a heterogeneous unit in which different genealogies encounter and merge. The subsequent chapters of Isabel's family narrative in the novel-which trace her lineage as well as her husband, Quintín's - lift the veil from the family secret that the allegedly white Mendizabal bloodline mixes with the family of the Mendizabals' Afro-Caribbean servant, Petra Avilés.

\section{Matrilineal Dialogues and Environmental Images}

Dialogism in Ferrés work enables Isabel to present the complexity of matrilineal connections by giving voice to women who are conventionally excluded from the official, patriarchal accounts of Puerto Rican historiography. In The House on the Lagoon, the notion of matrilineality extends beyond blood-relations, since the female figures portrayed also establish intersubjective relationships with women outside the immediate genetic bond between mother and daughter. This specific cultural practice of the Caribbean families is appropriately described with the anthropological term of "fictive kinship," which challenges blood kin and marital relationships as the only accepted cultural models by which familial bonds can be established (Chatters, Taylor, and Jajakody 1994, 297).

The gendered aspect of the multivoiced, heteroglossic narrative form of The House on the Lagoon is substantiated by the multiple stories of women that Isabel's manuscript presents as part of the family narrative. These incorporated stories underline that Isabel—due to her barely present dysfunctional mother, who suffers from mental illness-builds fictive kinship with women she identifies with across generational, racial, and class differences. These female figures are all victims of some form of patriarchal or racial oppression: Quintín's domestically abused mother, Rebecca Mendizabal; the publicly humiliated mulattas Doña Ermelinda and her daughter, Esmeralda Márquez; and the slave-descendent Carmelina, who is raped by Isabel's husband.

The most complex intercultural female bond, however, exists between Isabel and the Afro-Caribbean family servant, Petra. The interconnectedness between these women manifests on both character and narrative levels. Isabel's original structuring principle to interweave hers and Quintín's family genealogies considerably alters through the incorporation of a third lineage, Petra's bloodline, into the basic narrative fabric of family genealogy. As Isabel admits at the beginning of the novel, 
"My original purpose was to interweave the woof of my memories with the warp of Quintín's recollections, but what I finally wrote was something very different" (Ferré 1996, 6). This narrative gesture by Isabel to include Petra in the family saga does not only challenge the structure of the novel as a dialogue between the husband's and the wife's versions of the Mendizabal family history, but also elevates the black woman into a family member.

The family servant clearly embodies a destabilizing, or in a Bakhtinian sense, a "centrifugal force" (Bakhtin 1981, 272), and threatens to break down the integrity of the patriarchal historical narrative of national unity, the discourse that Quintín both stands for and maintains. Quintín's perception of the pure bloodline through generations of the family is endangered by Petra's interfering with Isabel's story, as well as Petra's mere existence and her familiarity with the family's past history. Serving three generations of Mendizabals, the black matriarch's extended family knowledge constantly haunts Quintín. He is convinced that Isabel's misrepresentations of the Mendizabal genealogy are influenced by Petra, who wants to take revenge on him for disinheriting Willie, his mulatto son born out of Quintín's rape of Petra's granddaughter, Carmelina. This is how Quintín expresses his overwhelming fear of Petra's invisible infiltration into Isabel's narratorial voice: "And behind Isabel's lens he felt Petra's malevolent eye following his ever step, listening to his every word" (Ferré 1996, 294). His suspicion toward Petra gradually increases and toward the end of the novel Quintín discovers that Isabel "was Petra's ally, and they were writing the manuscript together in order to destroy him" (Ferré 1996, 374).

As a representative of the slave-descendent, silenced black woman, the infiltration of Petra's voice into the genealogical stories of the elite family is highly subversive, since it fragments and stratifies the unitary construction of Puerto Rican nationality into further, internally dialogic layers of gender and racial differences. The novel's dialogic mobilization of these layers reconfigures the insular erasure of mestizaje into a relational and equally participatory dialogic discourse partaking in the construction of the collective Puerto Rican historical identity. Although Petra's voice remains confined within Isabel's narrative throughout the novel, she is agentic in deconstructing the semblance of racial and cultural homogeneity the Puerto Rican nation upholds. The maid fits into Bakhtin's notion of a posited author that the philosopher considers one of the basic ways of incorporating heteroglossia into the novel $(1981,323)$. As a posited author Petra's family knowledge is sedimented within Isabel's white authorial voice through which she conveys the family story. Thus, in Bakhtinian terms, Petra "speaks (albeit in a refracted way) by means of this story and through this story" (Bakhtin 1981, 314), in other words, through the novel-in-the-novel story written by Isabel. 
Petra's association with the slum area of the swamp, and more broadly, with the natural element of water accentuates that it is the Afro-Mestiza people and their spiritual energies gained from nature that nurture the bourgeois family and maintain their social hegemony. A predominant poetic image of the encounter between black spirituality and the white Puerto Rican elite is Petra's guardianship of a spring of curative waters located in the maze-like living quarters of the servants, the cellar. Isabel's accounts accentuate that as soon as the founder of the family, Spanish immigrant and Hispanophile Buenaventura Mendizabal brings Petra to the house, he takes advantage of her spiritual powers to maintain his class dominance and patriarchal family control. As Isabel describes: "Petra ran Buenaventura's bath with perfumed bay leaves every day, and once every two or three months she boiled all kinds of roots which she said had magical powers [...] Buenaventura was convinced Petra's baths helped him do good business" (Ferré 1996, 238).

The connection between water imagery and African spiritual powers is further enhanced by Petra's worship of an African deity, Elegguá, the God of crossroads in the Afro-Cuban belief system of Santería. ${ }^{1}$ Being a curandera (a folk healer) herself, Petra considers water as an extended kinship through which people can reconnect with their ancestors. The black matriarch's spiritual contact with Elegguá prompts reading Petra as the ultimate transmitter of family secrets about the racially and culturally mixed Mendizabal lineage. Toward the end of the novel the Catholic raised Isabel sacrificially offers her manuscript to Elegguá to protect it from Quintín, who decides to destroy it. In the retrospective narration in the last few chapters of the novel, Isabel reveals that it is due to her belief in the African deity that she could publish her writing, since the card-box where Petra hid Isabel's manuscript—along with other sacrificial objects offered to Elegguá-survives the arson in which the house on the lagoon burns to the ground. The house falls victim of a terrorist attack by Quintín's son, Manuel, a member of a radical political party, the Independistas. As Quintín is killed in the accident, the destruction of the house metaphorically alludes to the collapse of the Puerto Rican nationalism Isabel's husband represents.

Santeria, or "the way of saints," originates from sixteenth-century Cuba. It was developed by African slaves who fused their own spiritual practices with the belief systems of the Roman Catholic Church and French Spiritism (Norat 2005, 109 n5). 


\section{Concluding Remarks}

As I have demonstrated, the intersectional analysis of environmental theme and narrative form highlight the multilayered and multi-voiced structure of Ferrés family saga. Reading the conversational structure of the novel through the Bakhtinian concepts of dialogism and heteroglossia reveals how Ferrés portrayal of the domestic sphere of the Mendizabal family is deeply informed by competing political discourses of nature and culture, man and woman, working class and upper class, and the national myth of racial purity and the heterogenous nature of Puerto Rican cultural identity. Drawing on the interplay of ecological and cultural hybridity, Ferré demonstrates that in The House on the Lagoon the environment is not a mere setting, an inert backdrop against which plot events unfold. The waterbound images analyzed above are central to Ferrés decolonizing poetics through which she uncovers how Puerto Rican cultural hybridity is exploited in order to maintain the hegemony of the Mendizabal family, and by extension, the national ideology of whiteness they represent. As such, the novel recognizes the inherently diverse natural environment of Puerto Rico as a discourse which is instrumental for Ferré to narratively challenge the hegemonic political and national constructions of Puerto Rican identity.

\section{Works Cited}

Bakhtin, M. M. 1981. "Discourse in the Novel.” In The Dialogic Imagination: Four Essays, edited by Michael Holquist, 259-422. Austin: University of Texas Press. Chatters, Linda, Robert Taylor, and Rukmalie Jayakody. 1994. "Fictive Kinship Relations in Black Extended Families." Journal of Comparative Family Studies 25 (3): 297-312. https://doi.org/10.3138/jcfs.25.3.297.

Esplin, Marlene Hansen. 2015. "Self-Translation and Independence: Reading Between Rosario Ferrés The House on the Lagoon and La casa de la Laguna." Translation Review 92(1): 23-39. https://doi.org/10.1080/07374836.2015.1094432.

Ferré, Rosario. 1996. The House on the Lagoon. New York: Plume Books. Johnson, Kelli Lyon. 2008. "Mapping Puerto Rican Collective Memory in The House on the Lagoon." In Writing Off the Hyphen: New Critical Perspectives on the Literature of the Puerto Rican Diaspora, edited by José L. Torres-Padilla and Carmen Haydée Rivera, 239-255. Seattle: University of Washington Press.

Kevane, Bridget. 2000. "A Side View: An Interview with Rosario Ferré." Latina Self-Portraits: Interviews with Contemporary Women Writers, edited by Bridget A. 
Kevane, Bridget Kevane, and Juanita Heredia, 59-68. Albuquerque: University of New Mexico Press.

Moreno, Marisel C. 2012. Family Matters: Puerto Rican Women Authors on the Island and the Mainland. Charlottesville: University of Virginia Press.

Norat, Gisela. 2005. "Latina Grandmothers: Spiritual Bridges to Ancestral Lands." Journal of the Motherhood Initiative for Research and Community Involvement 7(2): 98-111. https://jarm.journals.yorku.ca/index.php/jarm/article/viewFile/ 4986/4180.

Sandín, Lyn Di Iorio. 2004. Killing Spanish: Literary Essays on Ambivalent US Latinola Identity. New York: Palgrave MacMillan. 